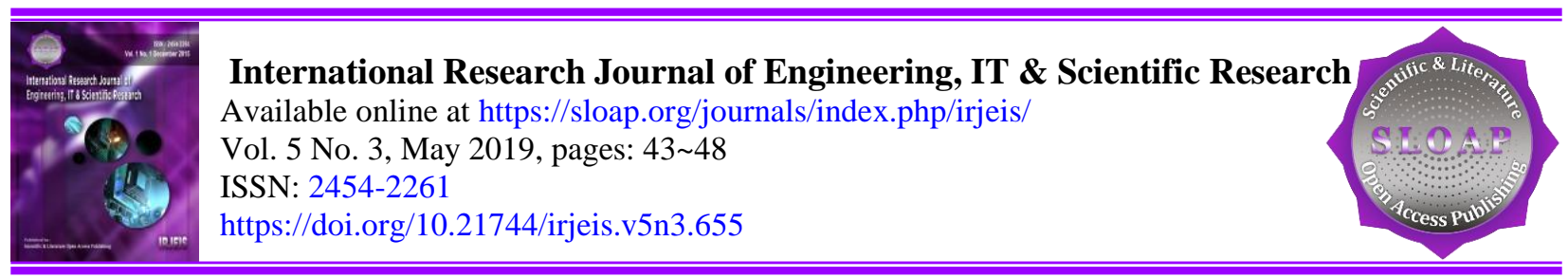

\title{
An Analysis of EFL Students' Anxiety Factors in Speaking
}

Achmad Sjaifullah ${ }^{\text {a }}$

Article history:

Received: 9 December 2018

Accepted: 31 March 2019

Published: 31 May 2019

\section{Keywords:}

anxiety factors;

EFL;

performance;

speaking;

students;

\begin{abstract}
EFL students' speaking performance is not only affected by cognitive, but also effective factors. Anxiety can explain why EFL students are hesitant to speak in the classroom. Anxiety can result from various causes, which are going to be described in this article. The current study was designed as a survey, employing the Foreign Language Classroom Anxiety (FLCA) questionnaire as the main instrument. The subjects of this study were 101 students from the Department of Chemical Engineering, State Polytechnic of Malang. The results of the item analysis showed that there were nine factors contributing to the participants' anxiety. These factors are manifested in the students' responses towards anxious behaviors that are interpreted as the results of students' low self-esteem, inconvenient classroom atmosphere, and peer pressure. The findings of this study can provide insights into the development of EFL students' speaking skills, especially those related to the affective domain.
\end{abstract}

2454-2261 ${ }^{\circledR}$ Copyright 2019. The Author. This is an open-access article under the CC BY-SA license (https://creativecommons.org/licenses/by-sa/4.0/) All rights reserved.

\section{Author correspondence:}

Achmad Sjaifullah,

Universitas Negeri Malang, Politeknik Negeri Malang, Indonesia

Email address: achmad.sjaifullah@polinema.ac.id

\section{Introduction}

Academic success is not only determined by cognitive factors, but also effective aspects. Anxiety is a negative feeling that can hinder learning in a destructive way. It is often associated with a lack of confidence, frustration, the feelings of being rejected and disturbed, and extreme fear and tense. These feelings lead to energy draining. Therefore, anxious learners are incapable of bringing out the best in themselves, especially under distress (Anandari, 2015; Arnold, 2000; Astuti, 2016).

Research shows that anxiety has a significant correlation with students' success in academics (peer pressure 3; self-esteem 2). Therefore, various remedies have been proposed to "cure" the causes. More importantly, the causes need to be identified in students. A study conducted in an Indonesian EFL context has established three primary concerns related to students' anxiety in English speech production The first one is the fear of being unable to deliver

${ }^{a}$ Universitas Negeri Malang, Politeknik Negeri Malang, Indonesia 
a message in English in an understandable way. Another cause of students' anxiety is shyness. This factor is commonly found in students. Shyness may lead to stage fright, uncontrollable movements when performing in front of the classroom, and stuttering (Bahrudin, 2018; Biduri, 2017; De Guzman, 2007). The third factor is discomfort. Discomfort may rise due to inconvenient classroom atmosphere. Students who feel relaxed studying in a particular safe condition will feel more motivated (Maba \& Mantra, 2017). Moreover, teachers find it easier to teach their students when their students feel relax and comfortable in the classroom (Mantra, 2017).

The causes of students' anxiety may vary depending on the context where English is taught, the characteristics of the students, and the location where the study is conducted. Therefore, this study sought to reveal other factors that may affect students' anxiety in a different Indonesian EFL context where English is taught for engineering purposes. The characteristics of the students are also different from the previous. While Anandari's involved English Department students as the participants, this study selected 101 students from the Department of Chemical Engineering who had studied English as General Purpose in their junior year (Deepika \& Prema, 2017; Deng et al., 2016; Horwitz et al., 1986).

\section{Materials and Methods}

The current study was designed as a survey which aimed to elicit EFL students' anxiety factors in speaking English. The study was carried out for seven months (from March 31 to October 31, 2017). It was conducted at the Department of Chemical Engineering, the State Polytechnic of Malang. The department holds two diploma levels, Diploma 3 (D3) and Diploma 4 (D4). At the time when this study was conducted, the department opened 2 classes for Diploma 3 and 6 classes for Diploma 4. The D3 students are offered two English courses which are held on the second and the fourth semester, while the D4 students have to take three English course offerings, namely English I, II, and III.

The subjects of this study were selected using a random sampling technique. In total, there were 101 students participating in this survey. The students came from two D3 classes and two D4 classes registered in the academic year of 2015/2016. The students were in their sophomore year when this study was conducted so that they had experienced learning English as a Foreign Language (EFL) before (English I for the D3 students and English I and II for the D4 students).

\section{Results and Discussions}

\subsection{Statistical Results of the Item Analysis}

The anxiety-level questionnaire was distributed to 101 students, but only 99 were returned. There were 9 factors successfully identified among the 31 items responded. The results of the factor analysis showed that the nine factors had a significant effect on the students' performance in English speech production (70,082\%).

Factor 1 is related to the students' dominant fear and anxiety in an English language classroom. This factor is represented by items no.2 (0.234), $14(0.134), 16(0.199), 18(0.261)$, and $19(0.292)$. Factor 2 is associated with the classroom atmosphere which also includes learning models and student diversity. This factor is represented by items no. 23 (0.268) and no 25 (0.332). Factor 3 includes students' lack of understanding of the teacher's explanation. This factor is shown by items no. $4(0.328), 7(0.237)$, and $15(0.340)$. Factor 4 is students' anxiety when asked to present in front of their peers (Items no. $24(0.446)$ and $27(0.152))$. Factor 5 is the students' low self-esteem. It is elicited from items no. 1 (0.198), $10(-0.123), 26(0.218), 28(0.283)$, and $32(0.515)$.

Factor 6 and 7 consist of students' confusion and stress in speaking a foreign language (Item no. 5(0,299), 13 $(0,411), 21(0,348), 22(0,225), 30(0,299))$. Factor 7 is represented by items $3(-0,208), 9(0,161), 31(0,720)$. Factor 8 is unpreparedness. This factor is depicted in items no. $12(-0,152), 17(0,703), 33(-0,218)$. Factor 9 adds to student unpreparedness that s lack of responsibility of learning (Items no. $6(0,613)$ and $8(0,394))$.

Since learning in the classroom cannot exist without "the presence of teacher and student", then both parties may take part in generating the nine anxiety factors. Thus, the nine factors can be categorized into student factors and teacher factors. The following sections will discuss further four major causes that can affect students' anxiety in speaking a foreign language. 


\subsection{Cause 1: Self-Esteem}

Apparently, self-esteem has a significant effect on students' speaking performance. Based on the results of the FLCAS, it was evident that students' anxiety in speaking rooted from their poor self-esteem, as has been mentioned by the students that "fear is dominant and feeling not confident enough to communicate in a foreign language is a barrier to produce oral speech in English". Self-esteem is an effective factor that might create imaginary barriers which inhibit foreign/second language acquisition. It has been reported that EFL students who have high self-esteem will also possess high oral proficiency compared to those who do not

\subsection{Cause 2: Classroom Atmosphere}

A positive classroom atmosphere will form a safe and comfortable space for students to learn. The results of the questionnaire showed that students' anxiety in producing oral English resulted from their insecurity and inconvenience being in the classroom. They mentioned that "classroom conditions, including the learning models used by the teacher and the diversity of the students, have affected the learning process". A supportive classroom atmosphere does not exist naturally; the teacher has to create it. Therefore, the role of the teacher is monumental. Teachers' encouraging speech and understanding and reliable attitudes provide a safe haven for students to express ideas and opinions. When students' trust in teacher has been built and a good relationship between two parties has been established, it will become much easier for the students to get involved actively in the classroom activities.

A supportive classroom atmosphere can also be created through the implementation of appropriate teaching models or strategies that may help students understand the learning materials better. Based on the results of the FLCAS, it was obvious that students felt anxious to use English in presentation and discussion because they often felt "confused" about the materials. They admitted that they were unable to understand the teacher's explanation. Their inability to master the content has resulted in their speaking anxiety because "they do not know what to say". Therefore, the teacher needs to be creative. It has been proven that a teacher's creativity has a significant effect on students' success in learning a foreign language. Besides, cooperative learning is also effective in improving students' ability in delivering their thoughts in English (MacIntyre \& Gardner, 1989; Mandokhail et al., 2018; Mr, 2016).

\subsection{Cause 3: Peer Pressure}

Anxiety is one of the effective factors that contribute to students' performance in acquiring a foreign/second language. Anxiety is strongly associated with worries, frustration, low self-confidence, fear, and tense. Anxiety is a response to external stimulation. Under an unfamiliar circumstance, someone might feel negative about what other people think about them. In an academic setting, peer pressure can be the major influence of students' anxiety in learning. Students, especially adolescents, are really affected by what their peers think about them. The results of the FLCAS indicate that the majority of students can get abruptly panicked once they are asked to speak in front of their peers because they are afraid their friends may laugh at their errors and funny accents.

Peer pressure has a negative correlation with students' academic achievement in general. It means that peer pressure plays an important role in lowering students' classroom performance. Students, especially adolescents, learn better by interacting and engaging with their peers. They, in fact, spend more time with friends at school rather than at home with the family. Given the situation that the subjects of this study came from various cities in the Province, they might be put in a situation where they were far from their family and thus had to hang out more often with their classmates or college-mates. Therefore, peer judgment, either it is good or bad, will leave a strong impression on them as individuals. Friendship among classmates or college-mates needs to be built as it allows students to develop necessary social skills to foster their confidence in learning. Minimizing peer pressure can be one of the best solutions to overcome anxiety in performing better in academics.

\section{Conclusion}

The results of the survey conducted in the current study have revealed three major causes that lead to students' anxiety in English speech production. They are self-esteem, classroom atmosphere, and peer pressure. Considering

Sjaifullah, A. (2019). An analysis of EFL students' anxiety factors in speaking. International Research Journal of

Engineering, IT \& Scientific Research, 5(3), 43-48. https://doi.org/10.21744/irjeis.v5n3.655 
these three aspects, it can be concluded that both students and teachers need to play an active role in minimizing students' anxiety in English classrooms. It is highly recommended for the English instructor to be more spontaneously creative and supportive towards students. Classroom management might be one of the most important skills English teachers should master professionally. As part of an education supporting system, schools need to consider integrating character education into the curriculum, such as teaching students how to respect their peers so that peer pressure can no longer exist in the classroom. It is also advisable for the students to find comfort in learning by recognizing their own learning styles. This study has not provided sufficient data on the effect of students' unpreparedness on their anxiety in speaking English. Thus, it is expected that future research can discuss the topic thoroughly.

Conflict of interest statement and funding sources

The author(s) declared that (s)he/they have no competing interest.

Statement of authorship

The author(s) have a responsibility for the conception and design of the study. The author(s) have approved the final article.

\section{Acknowledgments}

The author would like to thank the editor of IRJEIS for their valuable time, support, and advice in completing the current study. 


\section{References}

Anandari, C. L. (2015). Indonesian efl students'anxiety in speech production: possible causes and remedy. TEFLIN Journal, 26(1), 1-16.

Arnold, J. (2000). Seeing through listening comprehension exam anxiety. Tesol Quarterly, 34(4), 777-786. https://sci-hub.tw/https://doi.org/10.2307/3587791

Astuti, S. P. (2016). Exploring motivational strategies of successful teachers. Teflin Journal, 27(1), 1-22.

Bahrudin, D. V. Y. (2018). Improving Students' Speaking Ability on Expressing Plan through Problem Based Learning (PBL) Method. OKARA: Jurnal Bahasa dan Sastra, 12(2), 271-278. http://dx.doi.org/10.19105/ojbs.v12i2.2086

Biduri, F. N. (2017). The effect of teacher's creativity on native indonesian students'success in learning chinese language. okara: Jurnal Bahasa Dan Sastra, 11(2), 243-252. http://dx.doi.org/10.19105/ojbs.v11i2.1492

De Guzman, M. (2007). Friendships, peer influence, and peer pressure during the teen years.

Deepika, K., \& Prema, N. (2017). Peer Pressure in Relation to Academic Achievement of Deviant Students. International Journal of Environmental and Science Education.

Deng, X. Y., Liu, S. Z., Yan, P. E. N. G., \& Fu, Z. Z. (2016). The Research on the Affective Factors Which Influence Students' Performance in College English Classes. DEStech Transactions on Social Science, Education and Human Science, (icssd).

Horwitz, E. K., Horwitz, M. B., \& Cope, J. (1986). Foreign language classroom anxiety. The Modern language journal, 70(2), 125-132. https://doi:10.1111/j.1540-4781.1986.tb05256.x.

Maba, W., \& Mantra, I. B. N. (2017). An analysis of assessment models employed by the Indonesian elementary school teachers. International Journal of Social Sciences and Humanities, 1(1), 39-45. https://doi.org/10.29332/ijssh.v1n1.38

MacIntyre, P. D., \& Gardner, R. C. (1989). Anxiety and second-language learning: Toward a theoretical clarification. Language learning, 39(2), 251-275. https://doi.org/10.1111/j.1467-1770.1989.tb00423.x

Mandokhail, S., Khan, F. R., \& Malghani, M. (2018). Impact of ESL Learners' Self-Esteem on Their Oral Proficiency. International Journal Of English Linguistics, 8(3), 210-222.

Mantra, I. B. N. (2017). Promoting primary school teachers' competence through dynamic interactive workshop and partnership. International Journal of Linguistics, Literature and Culture, 3(1), 1-6.

Mr, E. R. (2016). Students'self esteem in speaking ability. Jurnal Smart, 2(2).

Sjaifullah, A. (2019). An analysis of EFL students' anxiety factors in speaking. International Research Journal of Engineering, IT \& Scientific Research, 5(3), 43-48. https://doi.org/10.21744/irjeis.v5n3.655 


\section{Biography of Author}

\begin{tabular}{|l|l||}
\hline \hline & $\begin{array}{l}\text { Achmad Sjaifullah is a senior lecturer in Politeknik Negeri Malang and currently } \\
\text { studying for his doctorate degree in Universitas Negeri Malang. He has been } \\
\text { conducting various researches in English language learning and Education for many } \\
\text { years since he started working as a university lecturer. His academic papers have } \\
\text { published in several academic research journals. } \\
\text { Email: achmad.sjaifullah@polinema.ac.id }\end{array}$ \\
\hline
\end{tabular}

